Bull. Fac. Agric., Cairo Univ.,65: 157-162 (2014).

\title{
EFFECT OF PLANTING DATES, BULB SIZES AND SHADING LEVELS ON THE GROWTH AND FLOWERING OF Iris hollandica
}

(Received: 28.3.2014)

\author{
By \\ A. A. AlSheikly \\ Horticulture \& Landscape Department, College of Agriculture, Diyala University, Iraq
}

\begin{abstract}
The present experiment was conducted at the Horticulture \& Landscape Department, Agriculture College, Diyala University, Iraq, during 2011-2012. The objective of the experiment was to study the effects of five planting dates $\left(1^{\text {st }}\right.$ Oct., $1^{\text {st }}$ Nov. $1^{\text {st }}$ Dec., $1^{\text {st }}$ Jan., and $1^{\text {st }}$ Feb.), three bulb sizes (5-6, 6-7 and 7-8 cm) and two levels of shading $(0$ and $50 \%)$ on the growth and flowering of Iris hollandica cv. Prof. Blaauw. The studied parameters included days for flowering, plant height, flower diameter, flowering stem diameter, flowering stem fresh weight, vase life and the fresh weight of bulbs and bulblets.

Planting dates and bulb sizes showed significant differences in all the studied parameters. Shading resulted significant differences with all studied parameters except flowering stem diameter and vase life. The interaction between planting dates and shading had significant differences in all the studied parameters, while the interaction between bulb size and shading level had significant differences with flower diameter, flowering stem diameter and fresh weight of the new bulbs. The best characteristics were obtained by early planting ( $1^{\text {st }}$ Oct. and $1^{\text {st }}$ Nov.) of larger bulbs $(7-8 \mathrm{~cm})$ under $50 \%$ shade.
\end{abstract}

Key words: bulb size, Iris hollandica cv. Prof. Blaauw, planting date, shading.

\section{INTRODUCTION}

Iris is a bulbous plant, its name, used by Theophrastus which means the Greek goddess of rainbow, is an apt name for a genus in which almost the entire color spectrum can be found. It contains more than 300 species, all native to the northern hemisphere. The genus belongs to family Iridaceae. Many species were found growing in the north of Iraq such as I. persica, I. barnumae and I.aucheri (Bryan, 2002) . Iris hollandica was developed from crosses between I. xiphium praecox, I. tingitana and I. Iusitanica, the most widly used cultivars are Wedgwood, Ideal, and Prof. Blaauw (Larson, 1980). In many countries Dutch Irieses are forced under greenhouse conditions to meet the peak consumer demands, and also grown in the field under minimal protection, where one of the limitations of field production is the lack of control of flowering time which takes 1 to 3 weeks only (Armitage and Laushman, 1990). In Iraq, the flowering time of
Prof. Blaauw variety is 10 to 15 days (Alsheikly, 2013). The present study was undertaken to standarize optimum planting date, bulb size and shade to achieve maximum growth, flowering, bulb production and present an attempt to extend flowering time.

\section{MATERIAL AND METHODS}

The experiment was conducted at the Research Station, Horticulture \& Landscape Department, College of Agriculture, Diyala University, during 2011-2012. The study consisted of five different plant dates $\left(1^{s t}\right.$ Oct, $1^{\text {st }}$ Nov., $1^{\text {st }}$ Dec., $1^{s t}$ Jan. and $1^{s t}$ Feb.), three sizes of bulb (5-6, 6-7 and 7-8 cm by circumference) and two levels of shade ( 0 and $50 \%$ ). Locally produced bulbs of Iris hollandica cv. Prof. Blaauw were planted in $15 \mathrm{~cm}$-diameter plastic pots (one bulb/pot) filled with sphagnum moss peat (Table 1) at $7 \mathrm{~cm}$ depth, half of the pots were placed under $50 \%$ net shade and the other half exposed to full sun (Irradiance was measured 
Table (1): Some physical and chemical properties of sphagnum moss peat medium used.

\begin{tabular}{|c|c|c|c|c|c|}
\hline \multirow{2}{*}{ pH } & \multirow{2}{*}{$\begin{array}{c}\text { EC } \\
\text { d. S. } \mathbf{m}^{-1}\end{array}$} & CEC & \multicolumn{3}{|c|}{ Element contents g.kg-1 $^{-1}$} \\
\cline { 4 - 6 } & $\mathbf{M e g} / \mathbf{1 0 0 g}$ & $\mathrm{N}$ & $\mathbf{P}$ & $\mathrm{K}$ \\
\hline 6.2 & 5.62 & 12.35 & 12.8 & 2.11 & 6.87 \\
\hline
\end{tabular}

with victor 1010 lux meter). Max. and Min. air temperatures were measured (Table 2). The routine agricultural practices were carried out as recommended for such plantation. Flowering time took place between 11 March and 5 April, the flowers were harvested in full opening stage and remaining 4 leaves on the plants as these are needed for the development of new bulbs and bulblets. The following data were recorded: days for flowering, plant height $(\mathrm{cm})$, flower diameter $(\mathrm{cm})$, flowering stem diameter $(\mathrm{mm})$, flowering stem fresh weight $(\mathrm{g})$, vase life (day), fresh weight of bulbs ( $\mathrm{g} / \mathrm{bulb}$ ) and bulblets (g/plant). The experiment layout was a randomized complete block design (RCBD) with three factors (5 planting dates, 3 bulb sizes and 2 shading levels) with 30 treatments with three replicates, All data were subjected to analysis of variance (ANOVA) and the means seperated using Duncan's Multiple Range test (Gomez and Gomez, 1984). significant effect to increase days for flowering. Similar results were also obtained by Cavins and Dole (2002) on narcissus and tulip. Interaction between planting dates and shading on number of days for flowering had a significant effect (Table 4), where the maximum number of days was in planting on $1^{\text {st }}$ Oct. irrespective of shading while the minimum was when planting on $1^{s t} \mathrm{Feb}$. in full sun.

\subsection{Plant height}

The means of analyzed data for plant height indicated that various planting dates significantly affected this character, where the maximum plant height was observed in those planted on $1^{\text {st }}$ Oct. $(45 \mathrm{~cm})$, while the minimum height was recorded when planting on $1^{\text {st }}$ Feb. (33.3cm) (Table 3). These results were confirmed by the findings of Armitage and Loushman (1990) who observed that delay in planting resulted in shorter stems of Iris. The same results were found by Aftab et al.,

Table (2) The daily means of Maximum and Minimum temperature 2011-2012 season $\left({ }^{\circ} \mathrm{C}\right.$ )

\begin{tabular}{|l|l|l|l|l|l|l|l|l|}
\hline $\begin{array}{l}\text { Month } \\
\text { Temp. }{ }^{\circ} \text { C }\end{array}$ & Oct. & Nov. & Dec. & Jan. & Feb. & March & April & May \\
\hline Max. & 31.6 & $\mathbf{2 3 . 8}$ & $\mathbf{1 8 . 8}$ & 19.5 & 20.6 & 25.1 & 35.3 & 39 \\
\hline Min. & 18.2 & 6.1 & 1.8 & 2.2 & 3.4 & 6.3 & 17.4 & 22 \\
\hline
\end{tabular}

\section{RESULTS and Discussion \\ 3.1. Days for flowering}

The mean values regarding days for flowering revealed that the different planting dates significantly affected days for flowering, the maximum was observed in those planted on $1^{s t}$ Oct. (166 days) while the minimum was in those planted on $1^{\text {st }}$ Feb. (60.2 days) These results were supported by Aftab et al. (2007) who found that earlier planting needs more days for flowering. Data presented in Table (3) exhibited that bulb size had a significant effect on days for flowering, bigger bulbs need more days for flowering (117.75 days) compared to small bulbs (114.80 days). These results were not on the same line with Alsheikly (2013) who observed that large bulbs of Dutch Iris produced flowers earlier. Data presented in (Table3) explained that shading had a
(2007) on Daffodil and Iris. Bulb size had a significant effect on this character, where the highest plant heights were recorded with large sized bulbs (Table 3). Similar results were reported by Alsheikly (2013) and Mane et al. (2007) on Iris hollandica and tuberose, respectively. This might be due to more stored food materials in large bulbs which helped in early and rapid vegetative growth of the plant. Plant height was influenced noticeably by shading, maximum of plant height $(45 \mathrm{~cm})$ was recorded with those growing under $50 \%$ shade and the minimum $(34.38 \mathrm{~cm})$ resulted from those growing in full sun (Table3). The same results were reported by Cavins and Dole (2002) on Narcissus and Tulip, and Mayoli and Isutsa (2012) on Ranunculus. Reduction of plant height in a full sun condition where light intensity ranges between 80 - 
$90 \mathrm{k}$ lux could be explained by the fact that leaves normally supply a gibberellin precursor to the stem and high light blocks the precursor's conversion to active gibberellins (Armitage, 1991). Interaction between planting dates and shading had a significant effect on plant height of Iris hollandica plants (Table 4).

\subsection{Flower diameter}

Data in Table (3) show that planting on $1^{\text {st }}$ Dec. differs significantly and produces the minimum flower diameter. This unexpected results may be due to the severe reduction in minimum temperature at late Dec. and early Jan. faced the sprouting bulbs. Researchers deal with Iris hollandica did not record significant differences in flower diameter due to planting dates (Aftab et al., 2007 and Armitage and Laushman, 1990). The data presented on bulb size in Table (3) revealed that large-sized bulbs produced the maximum flower diameter $(9.97 \mathrm{~cm})$ compared to the minimum $(9.33 \mathrm{~cm})$ produced by small bulbs, which might be based on the size of storage tissue of the bulb. These results are supported by Alsheikly (2013) who observed that larger bulbs of Iris hollandica produced maximum flower diameter. Similar results were found by Bhat et al. (2010) and Hatamzadeh et al., (2012) in gladiolus and tuberose respectively. Flower diameter was

Table (3): Effects of planting date, bulb size and shading on the studied characters of Iris hollandica cv.Prof Blaauw plant.

\begin{tabular}{|c|c|c|c|c|c|c|c|c|}
\hline Treatment & $\begin{array}{l}\text { Days for } \\
\text { flowering }\end{array}$ & $\begin{array}{c}\text { Plant } \\
\text { height }(\mathrm{cm})\end{array}$ & $\begin{array}{l}\text { Flower } \\
\text { diameter } \\
(\mathrm{cm})\end{array}$ & $\begin{array}{l}\text { Flowering } \\
\text { stem } \\
\text { diameter } \\
(\mathbf{m m})\end{array}$ & $\begin{array}{c}\text { Fresh } \\
\text { weight of } \\
\text { flowering } \\
\text { stem }(\mathrm{g})\end{array}$ & $\begin{array}{c}\text { Vase life } \\
\text { (day) }\end{array}$ & $\begin{array}{c}\text { Fresh } \\
\text { weight } \\
\text { of new } \\
\text { bulb } \\
\text { (g) }\end{array}$ & $\begin{array}{c}\text { Fresh } \\
\text { weight } \\
\text { of } \\
\text { bulblets } \\
\text { (g) }\end{array}$ \\
\hline \multicolumn{9}{|c|}{ Planting date } \\
\hline $\mathbf{1}^{s t}$ Oct. & $1660 a$ & 45.0a & $9.63 a$ & $7.77 b$ & 21.04a & 8.41a & 9.75a & $8.91 a$ \\
\hline $\mathbf{1}^{\text {st }}$ Nov. & $147.0 b$ & $40.8 \mathrm{~b}$ & $9.72 a$ & $8.16 a$ & $20.04 a$ & $8.25 a$ & $9.16 \mathrm{~b}$ & $8.25 a$ \\
\hline $\mathbf{1}^{s t}$ Dec. & $118.9 c$ & $39.2 \mathrm{~b}$ & $9.42 \mathrm{~b}$ & $7.20 \mathrm{c}$ & $16.37 b$ & $6.54 b$ & $7.04 c$ & $5.62 b$ \\
\hline $\mathbf{1}^{\text {st }}$ Jan. & 88.5d & $39.5 b$ & 9.72a & 6.69d & $14.62 \mathrm{c}$ & $5.79 \mathrm{c}$ & $6.25 \mathrm{~d}$ & $4.90 \mathrm{c}$ \\
\hline $\mathbf{1}^{s t}$ Feb. & $60.2 \mathrm{e}$ & 33.3c & $9.77 a$ & $5.30 \mathrm{e}$ & 9.10d & 4.62d & $5.00 \mathrm{e}$ & 3.03d \\
\hline \multicolumn{9}{|l|}{ Bulb size } \\
\hline $7-8 \mathrm{~cm}$ & 117.75a & 41.42a & $9.97 a$ & $7.69 a$ & $19.0 a$ & $7.90 \mathrm{a}$ & $8.55 a$ & $7.40 \mathrm{a}$ \\
\hline $6-7 \mathrm{~cm}$ & $116.05 b$ & 40.07a & $9.68 b$ & $6.96 \mathrm{~b}$ & $16.0 \mathrm{~b}$ & $6.77 b$ & $7.65 \mathrm{~b}$ & $6.37 b$ \\
\hline $5-6 \mathrm{~cm}$ & 114.8c & $37.60 b$ & $9.33 \mathrm{c}$ & $6.44 c$ & $13.7 \mathrm{c}$ & $5.50 \mathrm{c}$ & $6.12 \mathrm{c}$ & $4.72 \mathrm{c}$ \\
\hline \multicolumn{9}{|l|}{ Shading } \\
\hline $\mathbf{0}$ & 115.8b & 34.38b & $7.38 \mathrm{a}$ & $7.29 a$ & $15.63 \mathrm{~b}$ & $6.90 \mathrm{a}$ & $7.15 \mathrm{~b}$ & $5.91 b$ \\
\hline $50 \%$ & 116.6a & 45.01a & $9.93 a$ & $6.76 \mathrm{~b}$ & 16.86a & $6.55 a$ & $7.73 a$ & 6.41a \\
\hline
\end{tabular}

*Means in each column (and for each factor) having the same letter are not significantly different at $5 \%$ level of probability using Duncan test.

Table (4): Effects of the interaction between planting date and shading on the studied characters of Iris hollandica cv. Prof. Blaauw plant.

\begin{tabular}{|c|c|c|c|c|c|c|c|c|}
\hline Treatment & $\begin{array}{l}\text { Days for } \\
\text { flowering }\end{array}$ & $\begin{array}{c}\text { Plant } \\
\text { height } \\
(\mathrm{cm})\end{array}$ & $\begin{array}{l}\text { Flower } \\
\text { diameter } \\
\quad(\mathrm{cm})\end{array}$ & $\begin{array}{c}\text { Flowering } \\
\text { stem } \\
\text { diameter } \\
(\mathbf{m m})\end{array}$ & $\begin{array}{c}\text { Fresh } \\
\text { weight of } \\
\text { flowering } \\
\text { stem }(\mathrm{g})\end{array}$ & $\begin{array}{c}\text { Vase life } \\
\text { (day) }\end{array}$ & $\begin{array}{c}\text { Fresh } \\
\text { weight of } \\
\text { new bulb } \\
\text { (g) }\end{array}$ & $\begin{array}{c}\text { Fresh } \\
\text { weight of } \\
\text { bulblets } \\
\text { (g) }\end{array}$ \\
\hline$S_{0} \times P_{1}$ & $165.9 a$ & 38.0c & $9.55 \mathrm{bc}$ & 8.21ab & $22.16 a$ & 8.91a & $10.10 a$ & $9.50 \mathrm{a}$ \\
\hline $\mathbf{S}_{\mathbf{0}} \times \mathbf{P}_{2}$ & 147.5b & $36.8 \mathrm{~cd}$ & $9.44 c$ & $8.54 a$ & 19.33abc & $8.08 b$ & $9.00 \mathrm{~b}$ & $8.58 b$ \\
\hline $\mathbf{S}_{\mathbf{0}} \times \mathbf{P}_{\mathbf{3}}$ & $119.6 c$ & 32.6de & 8.00d & $7.12 \mathrm{c}$ & 14.16d & $6.16 \mathrm{c}$ & 5.91de & 4.58d \\
\hline$S_{0} \times P_{4}$ & 87.6d & 34.3d & $9.47 c$ & $7.05 c$ & $14.08 d$ & $6.25 \mathrm{c}$ & 6.00de & 4.08d \\
\hline $\mathbf{S}_{\mathbf{0}} \times \mathbf{P}_{5}$ & $58.3 f$ & $30.0 \mathrm{e}$ & $9.47 c$ & $5.53 \mathrm{e}$ & $8.41 \mathrm{e}$ & 8.08d & $4.60 \mathrm{e}$ & $2.83 f$ \\
\hline$S_{1} \times P_{1}$ & $166 a$ & $51.9 a$ & 9.75abc & $7.34 c$ & 19.91bc & $7.91 b$ & $9.33 b$ & 8.33b \\
\hline$S_{1} \times P_{2}$ & $147.4 b$ & $44.8 \mathrm{~b}$ & 10.01a & $7.79 b$ & 20.75ab & 8.41ab & $9.33 b$ & $7.91 \mathrm{~b}$ \\
\hline$S_{1} \times P_{3}$ & $118.3 c$ & $45.9 \mathrm{~b}$ & $9.85 \mathrm{ab}$ & $7.29 \mathrm{c}$ & $18.58 c$ & $6.91 \mathrm{c}$ & $8.16 \mathrm{c}$ & $6.66 \mathrm{c}$ \\
\hline$S_{1} \times P_{4}$ & 89.3d & $44.8 \mathrm{~b}$ & 9.96a & $6.33 \mathrm{~d}$ & 15.16d & $5.33 d$ & $6.50 \mathrm{~d}$ & $5.83 \mathrm{c}$ \\
\hline $\mathrm{S}_{1} \mathrm{xP}_{5}$ & $62.2 \mathrm{e}$ & $37.6 \mathrm{c}$ & 10.08a & $5.08 f$ & $9.9 \mathrm{e}$ & $4.16 \mathrm{e}$ & $5.33 \mathrm{e}$ & 3.33ef \\
\hline
\end{tabular}

- Shading level: $S_{0}=$ without shading, $S_{1}=$ shading 50\%, planting dates: $P_{1}={ }^{1 \text { st }}$ Oct....P $P_{5}={ }^{1 \text { st }}$ Feb.

- Means in each column having the same letter are not significantly different at $5 \%$ Level of probability using Duncan test. 
significantly affected by $50 \%$ shade which produced the maximum flower diameter $(9.93 \mathrm{~cm})$ compared to the minimum $(7.38 \mathrm{~cm})$ in full sun (Table 3). This may be explained by the fact that high light intensities seem to have exhausted plant food reserve and hence smaller flowers observed.
Interaction between bulb size and shading had significant effect. Table (5) shows that the maximum stem diameter $(8.79 \mathrm{~mm})$ was obtained by planting large bulbs in full sun and the minimum $(6.3 \mathrm{~mm})$ when planting small bulbs under $50 \%$ shade.

Table (5): Effects of interaction between shading and bulb size on some studied characters of Iris hollandica cv. Prof. Blaauw plant.

\begin{tabular}{|c|c|c|c|}
\hline Treatment & $\begin{array}{l}\text { Flower diameter } \\
(\mathbf{c m})\end{array}$ & $\begin{array}{c}\text { Flowering stem diameter } \\
(\mathbf{m m})\end{array}$ & $\begin{array}{c}\text { Fresh weight of new bulb } \\
(\mathrm{g})\end{array}$ \\
\hline$S_{0} \times B_{1}$ & $9.73 b$ & $8.79 a$ & $8.6 a$ \\
\hline$S_{0} \times B_{2}$ & $9.47 \mathrm{c}$ & $7.16 b$ & $7.2 \mathrm{~b}$ \\
\hline $\mathbf{S}_{\mathbf{0}} \times \mathbf{B}_{\mathbf{3}}$ & 8.96d & $6.58 \mathrm{~cd}$ & $5.6 \mathrm{c}$ \\
\hline $\mathbf{S}_{1} \times \mathbf{B}_{1}$ & $10.22 a$ & $7.29 \mathrm{~b}$ & $8.5 a$ \\
\hline$S_{1} \times B_{2}$ & $9.88 b$ & $6.76 \mathrm{c}$ & $8.1 a$ \\
\hline$S_{1} \times B_{3}$ & $9.70 \mathrm{c}$ & $6.30 \mathrm{~d}$ & $6.6 \mathrm{~b}$ \\
\hline
\end{tabular}

- Shading level: $S_{0}=$ without shading, $S_{1}=50 \%$, shading, Bulb size: $B_{1}=$ large bulb, $B_{2}=$ medium bulb, $B_{3}=s m a l l$ bulb.

Means in each column having the same letter are not significantly different at $5 \%$ Level of probability using Duncan test.

This is in accordance with the findings of Mayoli and Isutsa (2012) on ranunculus and with Armitage (1991) on zantedeschia. Interaction between planting dates and shading on flower diameter had a significant effect (Table 4); a significant effect of the interaction between bulb size and shading. Results in Table (5) show that the maximum flower diameter $(10.22 \mathrm{~cm})$ was obtained by planting big bulbs under $50 \%$ shade and the minimum $(8.96 \mathrm{~cm})$ was found when small bulbs were planted under full sun.

\subsection{Flowering stem diameter}

Planting dates had significant effect on flowering stem diameter of cv. Prof. Blaauw. The maximum stem diameter was observed in those planted on $1^{\text {st }}$ Nov. While the minimum was observed in those planted on $1^{\text {st }}$ Feb. (Table 3). These results are supported by Armitage and Laushman (1990) who observed that earlier planting dates (Nov., Dec.). of Anemone's bulbs produced the maximum stem diameter compared to later plantings (Jan., Feb.).

Bulb size had a significant effect on this character. The highest stem diameter $(7.69 \mathrm{~mm})$ was recorded when large bulbs were planted, and the lowest $(6.44 \mathrm{~mm})$ found when small bulbs were planted (Table 3). Similar results were obtained by Alsheikly (2013) on Iris hollandica. Planting in full sun gave the maximum stem diameter $(7.29 \mathrm{~mm})$ compared to $(6.76 \mathrm{~mm})$ for those planted under 50\% shade (Table 3). These results were confirmed by the findings of Mayoli and Isutsa (2012) on rununculus.

\subsection{Fresh weight of flowering stem (g/stem)}

Planting dates had significant effect on this character. The maximum fresh weight was obtained in those planted was on $1^{\text {st }}$ Oct. and $1^{\text {st }}$ Nov. and the minimum when planting on $1^{\text {st }}$ Feb. (Table 3). This increased weight was a reflection of increment in length and diameter of the flowering stem obtained in early planting. Fresh weight was influenced significantly by bulb size (Table 3). The larger bulb gave the higher fresh weight $(19 \mathrm{~g})$ compared to $(13.7 \mathrm{~g})$ produced by small bulb. Similar results were reported by Alsheikly (2013) who found that planting large bulbs of Iris hollandica produced the highest fresh weight. Similar results were recorded by El-Sayed (2012) on tuberose. Shading $50 \%$ produced the maximum (16.86 g) while the minimum fresh weight $(15.63 \mathrm{~g} / \mathrm{stem})$ was produced in full sun (Table 3). These findings were in general agreement with those obtained by Armitage (1991) on zantedeschia. Interaction between planting date and shading had significant effect on fresh weight of flowering stems, moreover, shading had also significant effect on fresh weight of flowering stems (Table 4).

\subsection{Vase life}

Data presented in Table (3) show that early planting on $1^{\text {st }}$ Oct. and $1^{\text {st }}$ Nov. resulted the longest vase life (8.41 and 8.25 days, respectively). The shortest (4.62 days) was produced by later planting on $1^{\text {st }}$ Feb. Bulb size had significant effect on this character (Table 3). The longest flower life (7.9 days) was observed 
when biggest bulbs planted and the shortest (5.5days) when planting small bulbs. AlSheikly (2013) found similar results on Iris hollandica, thereby confirming the present findings. Significant interaction was found between planting dates and shading on vase life.

\subsection{Fresh weight of bulb (g/bulb) and bulblets (g/plant)}

The responses of bulbs and bulblets were almost the same, the early planting significantly increased the fresh weight of bulbs and bulblets compared with late planting (Table 3). Similar results were reported by Aftab et al. (2007) on Iris hollandica, Daffodil and Freesia, who suggested that longer growing period promotes harvested bulb weight owing to more photosynthetic activity. Bulb size had significantly affected this character, the heaviest bulbs and bulbils were produced when large bulbs planted and the lightest when small bulb used (Table 3). Similar results were found by Al Sheikly (2013) on Iris hollandica, Bhat et al. (2010) on gladiolus and Ahmed et al. (2009) on tuberose. 50\% Shading recorded significant increase in fresh weight of bulbs and bulblets compared to those grown in full sun. Interactions between planting dates and shading (Table 4), bulb size and shading (Table 5) both had significant effect on fresh weight of bulb and bulblets.

\section{Conclusion}

Early planting, big bulbs and 50\% shade produce the best characteristics of Iris hollandica grown for cut flower production.

Growing Iris plants in ambient irradiance produced short compact plants which are suitable for pot plant production.

Extending planting dates can extend the harvesting time.

Late planting obviously need less days for flowering with decline in some characters, hence this planting needs more studies because of its economic advantage.

\section{REFERENCES}

Aftab M., Shabbir G. and Mahmood A. (2007). Production of high quality bulbous flowers in pothwar. International symposium on prospects of horticultural industry in Pakistan $28^{\text {th }}$ to $30^{\text {th }}$ March.

Ahmed I., Ahmed T., Asif M., Saleem M. and Akram A. (2009). Effect of bulb size on growth, flowering and bulbs production of tuberose. Sarhad J. Agric. 25(3):391-397.

Alsheikly A.A. (2013). Effect of bulb size and chemical fertilization on growth, flowering and bulbs production of Iris hollandica. Diyala Agric. Sci. J. 5 (2): 581-592.

Armitage A.M. and Loushman J. M. (1990). Planting date and in-ground time affect cut flowers of Liatris, Polianthus and Iris. Hort Sci., 25(10): 1239-1241.

Armitage A. M. (1991). Shade affects yield and stem length of filed - grown cut - flower species. Hort. Sci., 26 (9): 1174-1176.

Bhat Z. A., Paul T. M. and Siddiqui M. A. A. (2010). Influence of spacing and corm size on growth, development, flowering and corm production of gladiolus (Gladiolus gradiflorus) cv. White prosperity. Res. J of Agric. Sci. 1(3): 282-283.

Bryan J.E. (2002). Bulbs. Revised edition. Timber press, Portland, Oregon U.S.A.

Cavins T.J. and Dole J. M. (2002). Precooling, planting depth, and shade affect cut flower quality and perennialization of filed-grown spring bulbs. Hort. Sci., 37(1): 79-83.

El-Sayed B.A. (2012). Effect of Pot fertilization sources, bulb size and their interaction on growth and flowering of tuberose. (Polianthus tuberosa L.) Res. J. Agric \& Biol. Sci., 8 (2): 250-255.

Gomez K.A. and Gomez A.A. (1984). Statistical Procedures for Agricultural Research $2^{\text {nd }}$ Ed. John wiley, New yourk, USA.

Hatamzadeh A., Tehranifar A. and Akbari R. (2012). Effect of planting depth, bulb size and their interactions on growth and flowering of tuberose (Polianthus tuberosa L.) Am-Euros. J. Agric. \& Environ. Sci., 12 (11): 1452-1456.

Larson R.A. (1980). Introduction to floriculture, First edition, Academic press, New York, USA.

Mane P.K., Banker G. and Makne S. S. (2007). Influence of spacing, bulb size and depth of planting on flower yileld and quality of tuberose (Polianthus tuberosa L.) cv. Single. Indian J. Agric. Res., 41(1): 71-74.

Mayoli R. N. and Isutsa D. K. (2012). Relationships of light intensity and temperature with growth and development of preconditioned and shaded ranunculus plants under high altitude tropical conditions. Inter. J. Adv. Biotech. Res., 2 (1): 24-29. 


\section{تأثير مواعيد الزراعة وحجم الأبصال

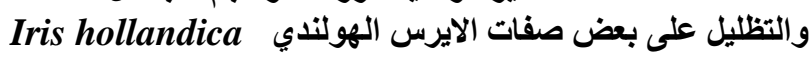 \\ عبد الرحمن الثخيلي \\ قسم البيتتة و هندسة الحدائقـ كلية الزر اعة - جامعة ديالى - العر اق}

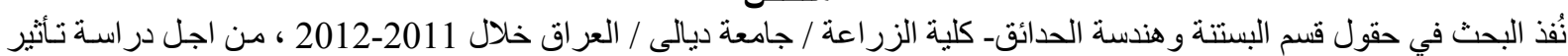

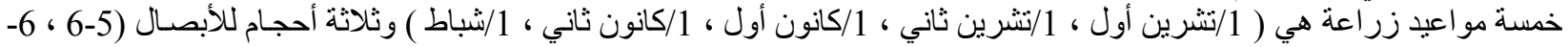

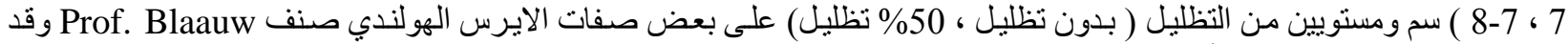

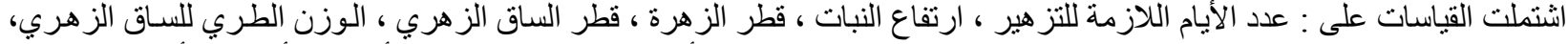

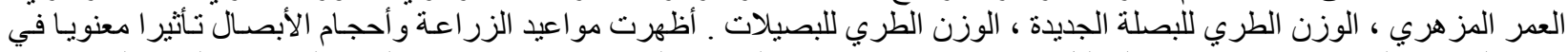

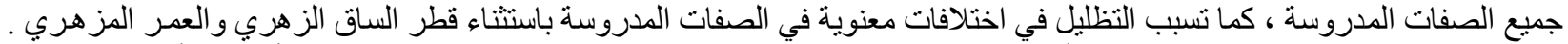

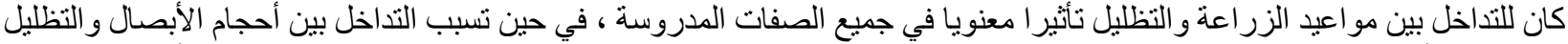

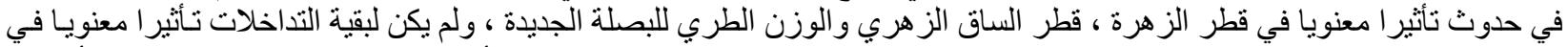

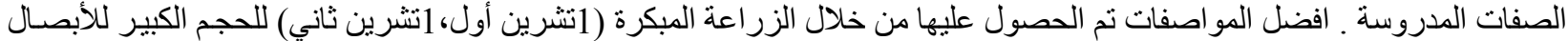
تحت 50\% ت نظليل. المجلة العلمية لكلية الزراعة - جامعة القاهرة ـ المجلد (65) العدد الثاني (أبريل 2014): 157-162. 